\title{
ANOTASI NORMATIF TERHADAP PERATURAN DAERAH TENTANG TRANSPARANSI
}

\author{
“NORMATIVE ANNOTATIONS TO REGIONAL \\ REGULATIONS ON TRANSPARANCY"
}

\author{
Nuvazria Achir ${ }^{1}$ \\ ${ }^{1}$ Fakultas Hukum Universitas Negeri Gorontalo, Gorontalo, Indonesia. Email: ulfa@ung.ac.id.
}

\section{Info Artikel}

\section{Kata Kunci:}

Landasan Pembentukan;

Peraturan Daerah;

Transparansi.

Cara Mengutip (APA

Citation Style):

Achir Nuvazria. (2020)."

Anotasi Normatif

Terhadap Peraturan

Daerah Tentang

Transparansi". Jambura

Law Review, JALREV 2

(1): 83-100

\begin{abstract}
Abstrak
Penyusunan Peraturan Perundang-udangan termasuk produk hukum Daerah (Perda) hendaknya menyesuaikan dengan sistem pembentukan hukum Nasional berdasarkan ketentuan terbaru dalam UU No. 12 Tahun 2011, serta memperhatikan prosedur dan tata cara yang baik guna menciptakan hubungan (harmonisasi) antara regulasi satu dengan lainnya. Dari hasil penelitian dapat disimpulkan bahwa, Perda Transparansi No 3 Tahun 2002 di Kota Gorontalo masih memiliki kekurangan dan kelemahan, khususnya dari latar belakang pembentukan yang belum memenuhi landasan dan asas penyusunan peraturan perundang-undangan termasuk memuat landasan hukum (yuridis) aturan terbaru sebagai rujukan yakni ketentuan UU Keterbukaan Informasi Publik. Selain itu, Perda belum mengimplentasikan UU No. 12 Tahun 2011 tentang Pembentukan Peraturan Perundang-undangan yang menginginkan penyusunan setiap produk hukum berlandaskan filosofis, sosiologis dan yuridis yang semuanya tercantum dalam lembaran Naskah Akademik serta memperhatikan asas pemberlakuan aturan berdasarkan kronologis pengeluarannya yaitu Undang-undang baru menyampingkan undang-undang yang lama atau (lex posteriori derogat lex priori), dan asas tingkatan Hirarki yang di dalamnya memuat ketentuan peraturan rendah (Perda) tidak mempunyai kekuatan hukum serta tidak mengikat apabila isinya bertentangan dengan ketentuan peraturan perundang-undangan yang lebih tinggi kedudukannya.

Oleh karena itu, dalam rangka memenuhi ketertiban hukum dan menguatkan keberadaan serta eksistensi Perda Transparansi, maka hal yang perlu dilakukan adalah menyesuaikannya dengan sistem penyusunan hukum nasional berdasarkan undang-undang No. 12 Tahun 2011 serta memperhatikan landasan dan asas pembentukan peraturan daerah yang baik.
\end{abstract}




\section{Article Info}

\section{Keywords:}

Basis Forming; Regional

Regulations;

Transparancy.

How to cite (APA Citation Style):

Achir Nuvazria . (2020).

"Normative Annotations of Regional Regulations on Transparancy".

Jambura Law Review, JALREV 2 (1): 83-100

\begin{abstract}
Compilation of Legislation including Regional legal products (Perda) regulates it according to the national legal system based on the latest provisions in Law Number 12 of 2011, and discuss procedures that can be used to produce relationships (harmonization) of one regulatin and others. From the results of the research, it can be concluded that the Regional Regulation on Transparency No. 3 of 2002 in Gorontalo City still has weaknesses, especially from the background of manufacture which has not met the foundation and principles governing legislation including the law, the juridical Law on Public Information. In addition, the Regional Regulation has not implemented Law Number 12 of 2011 concerning the Establishment of Legislation which invites every legal product based on philosophical, sociological and juridical relating to the writings of the Academic Manuscript as well as the principle of the application of chronological principles, old principles or (lex posteriori derogat lex priori), and the principle of the evaluation of Hierarchy described in Regional Legislation (Perda) does not have the legal force and is not binding, its contents are in accordance with the legislation that has a higher position of election.

Therefore, within the framework of fulfilling legal requirements and being strengthened and the existence of the Regional on Transparency, the thing that needs to be done is to adjust it to the national legal regulatory system based on law Number 12 of 2011 and discuss good regional regulatios.
\end{abstract}




\section{Pendahuluan}

Indonesia dalam konstitusi merupakan Negara Hukum yang perwujudannya tercermin ke dalam peraturan perundang-undangan yang dibuat untuk membatasi kekuasaan negara (pemerintah) dan memberi pedoman bagi rakyat dalam menjalankan aktivitasnya sebagai warga negara. Salah satu aspek penyelenggaraan pemerintahan khususnya di Negara ini adalah persoalan yang berkaitan dengan otonomi daerah yang salah satu prinsipnya adalah (asas) Desentralisasi, yaitu penyerahan kewenangan Pemerintah Pusat kepada daerah, dimana hal ini mencerminkan kemandirian daerah untuk berdiri sendiri dalam mengatur dan mengurus rumah tangganya. Hal yang lebih menguatkan lagi adalah pemberlakuan Undang-undang Nomor 32 Tahun 2004 tentang Pemerintah Daerah yang kemudian diubah ke dalam UU No. 23 Tahun 2014, yang mengatur secara pasti mengenai kewenangan daerah.

Adanya Desentralisasi kewenangan berdasarkan prinsip otonomi daerah, sesungguhnya telah melahirkan pembagian kewenangan termasuk penetapan peraturan perundang-undangan untuk menyelenggarakan pemerintahan, yang salah satu produk hukumnya adalah Peraturan Daerah, (selanjutnya disebut Perda). Pasal 18 ayat (6) UUD Negara Republik Indonesia Tahun 1945 menegaskan Pemerintah Daerah berhak menetapkan peraturan daerah dan peraturan-peraturan lain untuk melaksanakan otonomi dan tugas pembantuan.

Sementara itu, hakikat otonomi daerah menurut Ateng Syafrudin ${ }^{1}$, adalah untuk mengatur dan mengurus rumah tangganya sesuai dengan peraturan perundangundangan yang berlaku, artinya keberadaan perda tidak bisa lepas dari peraturan perundang-undangan yang berlaku secara nasional dan menyeluruh. Dapat diberi makna pula bahwa perda merupakan instrumen hukum yang dibuat oleh pemerintah di daerah dalam menyelenggarakan kewenangannya untuk mewujudkan otonomi yang dimiliki, disamping sebagai penjabaran lebih lanjut dari peraturan perundangundangan lebih tinggi.

Sebagai Negara Hukum berdasarkan Pasal 1 Ayat 3 UUD NRI, Indonesia meletakkan segala sesuatu berdasarkan koridornya masing-masing termasuk mengatur tingkatan

\footnotetext{
${ }^{1}$ Ateng Syafrudin. (1985). "Pasang Surut Otonomi Daerah”. Bandung: Binacipta Press. Hal. 5
} 
produk hukum (regulasi). Konsekuensinya adalah produk hukum yang disusun hendaknya memperhatikan kedudukan dari yang lebih tinggi sampai paling rendah, termasuk landasan dan asas pembentukannya.

Maria Farida ${ }^{2}$ mengatakan bahwa, dilihat dalam perspektif hukum positif di Indonesia maka hierarki peraturan perundang-undangan dan tercantum pada desain Teory Nawiasky adalah disusun secara berjenjang (piramida), dengan fungsi sebagai tolok ukur bagi peraturan perundang-undangan yang ada dibawahnya terhadap perundangundangan yang ada di atasnya. Adanya tata aturan yang berjenjang ini maka kekuatan hukum berjenjang pula. Dalam arti bahwa bagi peraturan yang lebih tinggi mempunyai kekuatan hukum yang lebih tinggi pula. Demikian sebaliknya, peraturan yang lebih rendah mempunyai kekuatan hukum yang lebih rendah.

Lahirnya berbagai produk hukum tertulis baik di tingkat Pusat maupun daerah terkadang menimbulkan berbagai polemik, seperti menyangkut harmonisasinya (hubungan antara satu sama lain), batas pemberlakuan sampai dengan struktur maupun hierarki (tata urutan) peraturan perundang-undangan yang tidak boleh bertentangan baik itu substansi maupun materi muatan berdasarkan batasan kewenangan sesuai jenis peraturan perundang-undangan.

Bagir Manan ${ }^{3}$ mengatakan bahwa, penyusunan peraturan perundang-undangan tingkat daerah bukan sekedar melihat batas kompetensi formal atau kepentingan daerah yang bersangkutan, tetapi harus dilihat pula kemungkinan dampaknya terhadap daerah lain atau kepentingan nasional secara keseluruhan dan penyusunannya tidak bisa lepas dari sistem perundang-undangan Nasional.

Ketentuan pasal 7 ayat (1) Undang-undang Nomor 12 Tahun 2011 tentang Pembentukan Peraturan Perundang-undangan, yang menegaskan bahwa jenis dan hierarki Peraturan Perundang-undangan terdiri atas :

1. $\quad$ Undang-Undang Dasar Negara Republik Indonesia Tahun 1945;

\footnotetext{
${ }^{2}$ Maria Farida Indrati. (2007). “Ilmu Perundang-undangan(1)”. Yogyakarta: Kansius (Cempaka) Press. Hal. 44

3 Bagir Manan. (1995). "Sistem dan Teknik Pembuatan Peraturan Perundang-undangan Tingkat Daerah”. Bandung: Pusat Penerbitan Universitas LPPM Universitas Islam Bandung Press. Hal. 8-9
} 
2. Ketetapan Majelis Permusyawaratan Rakyat;

3. Undang-Undang/Peraturan Pemerintah Pengganti Undang-Undang;

4. Peraturan Pemerintah;

5. Peraturan Presiden;

6. Peraturan Daerah Provinsi; dan

7. Peraturan Daerah Kabupaten/Kota.

Sementara itu, landasan dan Azas Pembentukan Peraturan Perundang-undangan menurut M.Solly Lubis ${ }^{4}$, ada tiga (3) landasan pembuatan peraturan perundangundangan, yakni;

(a) landasan filosofis yaitu dasar filsafat, pandangan atau ide yang menjadi dasar cita-cita sewaktu menuangkan hasrat dan kebijaksanaan (pemerintahan) ke dalam suatu rencana atau draft peraturan negara .

(b) landasan yuridis, ialah ketentuan hukum yang menjadi dasar hukum bagi pembuatan suatu peraturan, dan

(c) landasan politis, ialah garis kebijaksanaan politik yang menjadi dasar selanjutnya bagi kebijaksanaan dan pengarahan ketata-laksanaan pemerintahan negara.

Sementara itu Amiroeddin Syaif ${ }^{5}$ menegaskan, bahwa dalam perundang-undangan dikenali atas 5 (lima) asas yakni;

1) asas tingkatan hirarki,

2) Undang-undang tidak dapat diganggu gugat,

3) Undang-undang yang bersifat khusus menyampingkan undang-undang yang bersifat umum (lex specialis derogat lex generalis),

4) Undang-undang tidak berlaku surut,

5) Undang-undang yang baru menyampingkan undang-undang yang lama (lex posteriori derogat lex priori).

\footnotetext{
${ }^{4}$ Suprin Na'a. (2004). "Perda dalam Perspektif Ilmu Perundang-undangan”. Palu: Tadulako University Press. Hal.75-76

5 Ibid. Hal. 79
} 
Berkenaan dengan asas-asas peraturan perundang-undangan ini, Purnadi Purbacaraka $^{6}$ dan Soerjono Soekanto pun memperkenalkan pula enam (6) asas perundang-undangan yaitu;

(a) Undang-undang tidak berlaku surut,

(b) Undang-undang yang dibuat oleh penguasa yang lebih tinggi mempunyai kedudukan yang lebih tinggi pula,

(c) Undang-undang yang bersifat khusus menyampingkan undang-undang yang bersifat umum (lex specialis derogat generali),

(d) Undang-undang yang berlaku belakangan membatalkan undang-undang yang berlaku terdahulu (lex posteriori derogat lex priori),

(e) Undang-undang tidak dapat diganggu gugat, dan

(f) Undang-undang sebagai sarana untuk semaksimal mungkin dapat mencapai kesejahteraan spiritual dan material bagi masyarakat maupun individu, melalui pembaharuan/pelestarian (asas welvaarstaat).

Fenomena saat ini, lahirnya berbagai bentuk produk hukum di daerah terkadang dinilai bertentangan dengan ketentuan peraturan pusat, seperti adanya perda Syariah (agama) yang menurut sebagian orang tidak berdasarkan kebutuhan dan menyalahi hak asasi manusia orang lain, termasuk persoalan keberadaan perda yang tidak sesuai lagi harapan masyarakat, bahkan bertentangan dengan aturan perundang-undangan lebih tinggi.

Banyaknya perda yang dibatalkan baik di tingkat provinsi maupun kabupaten/kota, sebagian besar karena regulasi tersebut belum mengikuti pedoman dan teknik penyusunan Peraturan Perundang-undangan yang baik termasuk landasan dan asas pembentukannya.

Menyikapi berbagai persoalan yang berkaitan dengan penyusunan produk hukum di daerah, keberadaan Peraturan Daerah No. 3 Tahun 2002 di Kota Gorontalo telah ada sebelum UU Keterbukaan Informasi lahir (KIP). Saat ini implementasi Perda Tranparansi masih dilakukan pemerintah kota Gorontalo, sementara dilihat dari beberapa pasal substansinya memiliki kemiripan dengan UU No. 14 Tahun 2008.

\footnotetext{
${ }^{6}$ Purnadi Purbacaraka. (1993). "Perundangan-undangan dan Yurisprudensi”. Bandung: Citra Aditya Bakti Press. Hal. 7-12
} 
Pemerintah Daerah sendiri meyakini, bahwa lahirnya UU KIP berawal dari hasil kunjungan Pemerintah Pusat ke daerah yang sudah lebih dulu menerapkan Perda Transparansi.

Maka ini perlu dikaji dari berbagai aspek terutama landasan penyusunan Perda, baik secara filosofis, yuridis maupun sosiologis. Selain itu, perlu dilihat asas pembentukannya agar tidak tumpang tindih serta kesesuaiannya dengan hierarki peraturan.

Berdasarkan latar belakang di atas, penulis tertarik untuk mengkaji mengenai latar belakang penyusunan Perda Transparansi di Kota Gorontalo, yang diberi judul Kajian Yuridis Perda Transparansi di Kota Gorontalo Ditinjau dari Landasan dan Asas Pembentukan Peraturan Perundang-undangan (Studi Kasus Perda No. 3 Tahun 2002).

\section{Rumusan Masalah}

Dari latar belakang yang telah diuraikan di atas, dapat dirumuskan permasalahan yang perlu diteliti dan dibahas yakni bagaimana kajian yuridis Perda Transparansi Kota Gorontalo ditinjau dari Landasan dan asas pembentukan peraturan perundangundangan.

\section{Metode}

Penelitian ini merupakan jenis penelitian normatif. Penelitian hukum normative menurut Soerjono Soekanto ${ }^{7}$, mencakup penelitian asas-asas hukum, sistematika hukum, taraf sinkronisasi vertikal dan horizontal, penelitian sejarah dan perbandingan hukum. Peneliti juga melakukan penelitian lapangan untuk melengkapi data yang diperoleh secara langsung dari sumber pertama (primer) yang dipertegas oleh Sudikno ${ }^{8}$, bahwa penelitian kepustakaan dapat berdiri sendiri dan dapat pula dilengkapi dengan penelitian lapangan. Adapun sumber Data dalam penelitian ini yakni Bahan Hukum Primer dan Sekunder.

\footnotetext{
7 Soerjono Soekanto. (2007). "Pengantar Penelitian Hukum”. Jakarta : UI-Press. Hal. 51

8 Sudikno Mertokusumo. (2006). "Penemuan Hukum (Sebuah Pengantar)”. Yogyakarta: Liberty Press. Hal. 29
} 
Untuk mengumpulkan data penulis menggunakan teknik pengumpulan berupa penelitian kepustakaan (library research), penelitian lapangan (field research), melalui interview atau wawancara dan observasi (pengamatan). Sementara analisis data menggunakan metode deskriptif analitis dimana peneliti menguraikan dan memberikan gambaran berupa penjelasan data yang diperoleh melalui pengamatan dan kemudian dianalisa berdasarkan teori dan asas yang berlaku serta membuat prediksi maupun implikasi, kemudian diberikan kesimpulan.

Statute approach merupakan jenis pendekatan yang dilakukan peneliti termasuk pendekatan historis (historical approach), yakni dengan menelaah latar belakang pembentukan Perda, landasan hukum pembentukan serta maksud dan tujuan (alasan) pemberlakuannya. Pendekatan komparatif (comparative approach) juga dilakukan peneliti dengan membandingkan antara Perda dengan UU Keterbukaan Informasi Publik, yang dititikberatkan pada konsistensi perundang-undangan, keselarasan dan harmonisasinya.

\section{Pembahasan}

Aspek maupun pengaturan hukum tentang penyelenggaraan pemerintahan Kota Gorontalo yang tercantum dalam Perda Transparansi secara garis besar meliputi;

1) Informasi seluruh proses perencanaan pembangunan (Visi, Misi dan Strategi) mulai dari tingkat kelurahan sampai dengan tingkat kota.

2) Informasi pembahasan APBD mulai dari penganggaran sampai dengan pembahasan dan penetapan.

3) Informasi yang berkaitan dengan penataan Tata Ruang Kota Gorontalo.

4) Informasi proses pengawasan mencakup obyek yang diawasi sampai hasil-hasil audit.

5) Proses perjanjian dan kontrak kerja sesuai dengan kewenangan masing-masing badan publik.

Perda Transparansi terdiri dari $11 \mathrm{BAB}, 40$ pasal meliputi :

- Bab I berisi Ketentuan Umum yang terdiri dari 1 pasal dan 18 ayat.

- Bab II berisi Kewajiban dan Hak yang terdiri dari 9 pasal. Pasal 2 mengatur tentang Kewajiban yang meliputi Informasi, Prosedur, dan Pengambilan Kebijakan. Pasal 3 dan Pasal 4 berisi Informasi Yang Wajib Diumumkan Secara Aktif. Pasal 5, Pasal 6 dan Pasal 7 berisi tentang Informasi Yang Wajib Tersedia Setiap Saat. Pasal 8 yang berisi tentang Informasi Yang Wajib Diumumkan 
Secepatnya. Pasal 9 yang berisi tentang Prosedur. Pasal 10 yang berisi tentang Proses Pengambilan Kebijakan.

- Bab III berisi Hak Masyarakat Terhadap Badan Publik Informasi yang terdiri dari 3 pasal. Pasal 11 dan Pasal 12 yang berisi tentang Prosedur, dan Pasal 13 yang berisi tentang Pengambilan Kebijakan.

- Bab IV berisi Informasi Yang Dikecualikan yang terdiri dari 1 pasal yaitu Pasal 14 dan terdiri dari 4 ayat.

- Bab V berisi Komisi Transparansi yang terdiri dari 6 pasal. Pasal 15. Pasal 16 yang berisi tentang Kedudukan. Pasal 17 yang berisi Tentang Susunan. Pasal 18, Pasal 19 dan Pasal 20 yang berisi tentang Pengangkatan dan Pemberhentian Komisi Transparansi.

- Bab VI berisi Tugas, Fungsi Dan Wewenang Komisi Transparansi yang terdiri dari 7 pasal. Pasal 21. Pasal 22 yang berisi tentang Tugas. Pasal 23 yang berisi tentang Fungsi. Pasal 24, Pasal 25, dan Pasal 26 yang berisi tentang wewenang. Pasal 27 yang berisi tentang Mekanisme Pengaduan Kepada Komisi Transparansi.

- Bab VII berisi Keberatan yang terdiri dari 3 Pasal. Pasal 28, Pasal 29 dan Pasal 30.

- Bab VIII berisi Anggaran Dan Biaya yang di terangkan pada Pasal 31 dan Pasal 32.

- Bab IX berisi Sanksi Pidana yang terdiri dari 6 pasal. Pasal 33, Pasal 34, Pasal 35, Pasal 36, Pasal 37 dan Pasal 38.

- Bab X berisi Ketentuan Peralihan yang terdiri dari 1 pasal yaitu Pasal 39.

- Bab XI berisi Ketentuan Penutup yang terdiri dari 1 pasal yaitu Pasal 40.

Peraturan Daerah Nomor 3 Tahun 2002 ditetapkan Walikota Gorontalo Medi Botutihe, tanggal 13 Maret 2002. Mulai diberlakukan di Gorontalo pada tanggal 27 Maret 2002 dan diundangkan Sekretaris Daerah Kota Gorontalo Abdul Wahab Thalib dalam Lembaran Daerah Kota Gorontalo tahun 2002 Nomor 03 seri E.

Kepala Bagian Hukum Pemerintah Kota Gorontalo yang pada saat itu dijabat Adhi Mo'o SH mengatakan, bahwa lahirnya Perda Transparansi jauh sebelum adanya UU yang mengatur hal serupa, yakni (UU No. 14 Tahun 2008) tentang Keterbukaan Informasi Publik. Menurut Kabag Hukum bahwa Perda Transparansi dalam pembahasannya telah melalui kajian beberapa unsur antara lain Kepolisian, Kejaksaan, Pemerintah Kota dan Unsur DPRD Kota Gorontalo yang menjadi bukti adanya komitmen Pemkot Gorontalo dalam hal memberikan pelayanan kepada masyarakat khususnya dibidang informasi pembangunan daerah. Namun disayangkan penyusunannya belum mengikutsertakan pihak akademisi (Perguruan Tinggi). Hadirnya Komisi Transparansi yang dibentuk oleh DPRD merupakan komitmen dalam penyelenggaraan dan pengimplementasian Perda. 


\section{Landasan Pembentukan Peraturan Daerah}

\section{a. Landasan Filosofis dan Sosiologis}

Salah satu bagian terpenting dalam pembentukan Perundang-undangan termasuk perda transparansi adalah landasan filosofis yakni terkait nilai yang berkembang dalam masyarakat dan sosiologis adalah harapan masyarakat dimana menjadi bagian terpenting dalam memberikan pandangannya sebelum dilakukan penerapan regulasi yang diinginkan dan dicita-citakan masyarakat sebagai objek pelaksanaan aturan. Perda Transparansi sepatutnya memuat Naskah Akademik (NA) sebagai penjabaran landasan pembentukannya, mengingat hal ini telah diatur dalam ketentuan perundang-undangan seperti yang tercantum dalam UU No. 12 Tahun 2011 pasal 19 dan 48 , yakni pengajuan rancangan peraturan disertai dengan NA.

Selain itu, keberdaan Naskah Akademik menjadi bahan untuk mengupas tuntas sejauh mana Perda tersebut penting baik untuk memuat fakta serta problematika yang ada termasuk latar belakang maksud dan tujuan yang jelas. Akan tetapi, hal ini belum direalisasikan dalam pembentukan perda transparansi, mengingat waktu pembentukan Peraturan Daerah Transparansi jauh sebelkum ada ketentuan UU NO 12 Tahun 2011.

Mestinya Naskah Akademik yang berisi hasil penelitian dan pengkajian hukum dimasukkan dalam Perda Transparansi yang dapat dipertanggungjawabkan secara ilmiah serta sebagai solusi terhadap permasalahan dan kebutuhan hukum masyarakat. Selain juga, menjadi wadah untuk menampung dan menghimpun aspirasi serta kepentingan masyarakat yang kemudian menjadi bahan pengaturan produk regulasi daerah.

\section{b. Landasan Yuridis}

Setiap peraturan yang disusun hendaknya memiliki dasar yuridis guna untuk legitimasi (legalitas) sekaligus memberi penegasan terkait derajat (hierarki) dalam pengaturan perundang-undangan secara nasional. Alasan penting lainnya adalah agar peraturan perundang-undangan yang dibuat, dilaksanakan sesuai kewenangan lembaga negara maupun pemerintah (pusat dan daerah) yang mengeluarkan aturan tersebut. 
Kaitannya dengan Perda Transparansi, Peneliti melihat dan mengkaji belum ada kesesuaian khususnya norma hukum. Perda Transparansi seyogianya menjadikan UU KIP No. 14 Tahun 2008 sebagai salah satu landasan yuridisnya, mengingat materi muatan yang ada dalam aturan ini secara menyeluruh mengatur hal serupa yang terdapat dalam Perda yang notabene merupakan aturan dengan tingkatan lebih rendah.

Berikut peneliti sedikit menguraikan fakta mengenai keberadaan kedua aturan yang tercantum dalam tabel di bawah ini :

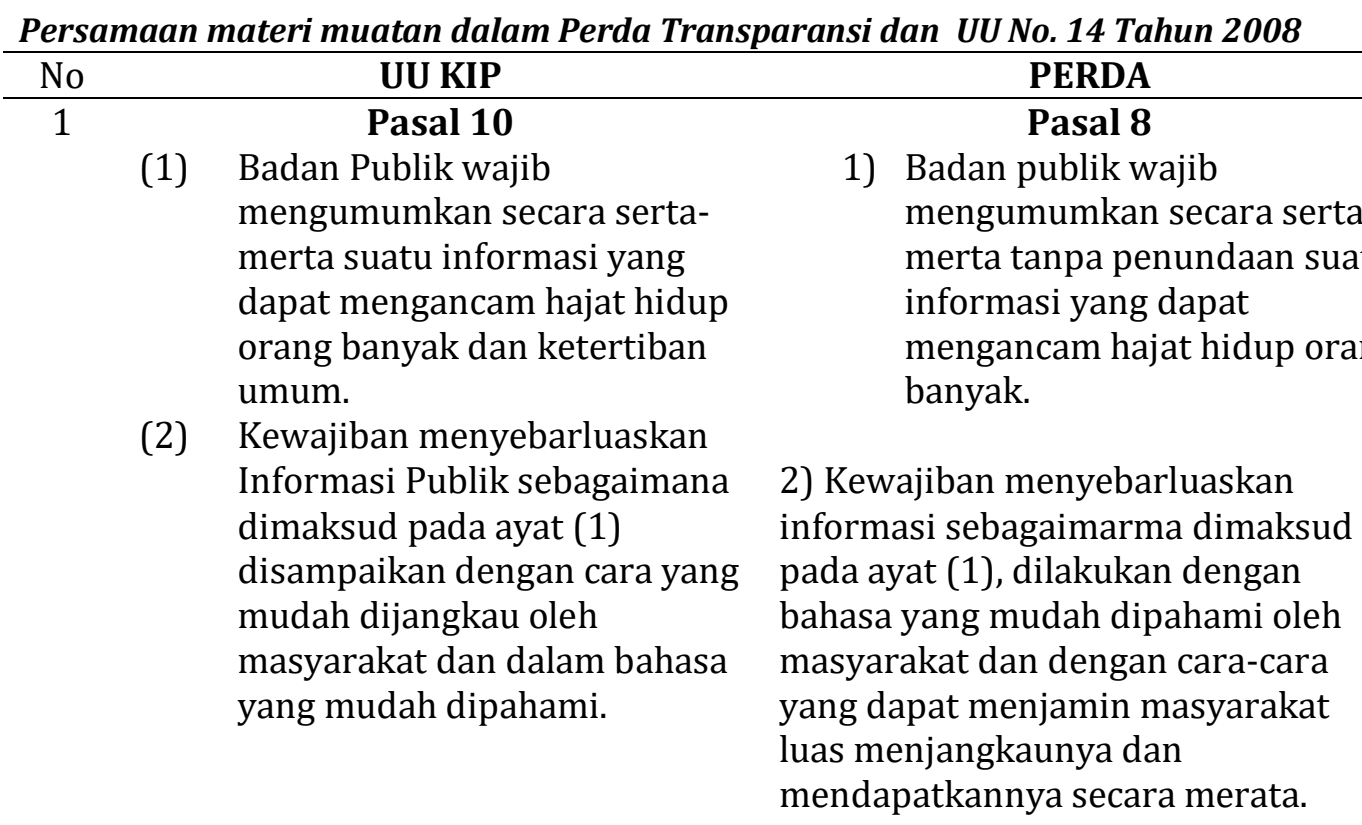

\section{2 \\ INFORMASI YANG DIKECUALIKAN} Pasal 17

Setiap Badan Publik wajib membuka akses bagi setiap Pemohon Informasi Publik untuk mendapatkan Informasi Publik, kecuali:

a. Informasi Publik yang apabila dibuka dan diberikan kepada Pemohon Informasi Publik dapat menghambat proses penegakan hukum, yaitu informasi yang dapat:

1. menghambat proses penyelidikan dan penyidikan suatu tindak pidana; 2. mengungkapkan identitas informan, pelapor, saksi, dan/atau korban yang mengetahui adanya tindak pidana;

\section{BAB IV \\ INFORMASI YANG DIKECUALIKAN}

\section{Pasal 14}

Setiap badan publik wajib membuka akses bagi setiap orang untuk mendapatkan informasi publik, kecuali :

1) Informasi publik yang apabila dibuka dan diberikan kepada orang dapat menghambat proses penegakan hukum, yaitu informasi publik yang apabila dibuka dapat :

a. Mengungkapkan identitas informasi, pelapor, pengadu, saksi, dan / atau korban yang mengetahui adanya kejahatan, atau ;

b. Mengungkapkan data intelejen kriminal dan rencana-rencana yang berhubungan dengan pencegahan 


\begin{tabular}{|c|c|}
\hline $\begin{array}{l}\text { 3.mengungkapkan data intelijen } \\
\text { kriminal dan rencana rencana yang } \\
\text { berhubungan dengan pencegahan } \\
\text { dan penanganan segala bentuk } \\
\text { kejahatan transnasional; } \\
\text { 4.membahayakan keselamatan dan } \\
\text { kehidupan penegak hukum } \\
\text { dan/atau keluarganya; dan/atau } \\
\text { 5.membahayakan keamanan } \\
\text { peralatan, sarana, dan/atau } \\
\text { prasarana penegak hukum. } \\
\text { b. Informasi Publik yang apabila } \\
\text { dibuka dan diberikan kepada } \\
\text { Pemohon Informasi Publik } \\
\text { dapat mengganggu kepentingan } \\
\text { perlindungan hak atas kekayaan } \\
\text { intelektual dan perlindungan } \\
\text { dari persaingan usaha tidak } \\
\text { sehat; }\end{array}$ & $\begin{array}{l}\text { dan penanganan kegiatan kriminal } \\
\text { dan terorisme, atau; } \\
\text { c. Membahayakan keselamatan dan } \\
\text { kehidupan petugas penegak hukum } \\
\text { dan / atau keluarganya, atau : } \\
\text { d. Membahayakan keamanan } \\
\text { peralatan, sarana / prasarana } \\
\text { penegakan hukum. }\end{array}$ \\
\hline
\end{tabular}

\section{Sumber : Perda Transparansi \& UU KIP}

\section{c. Landasan Politis}

Landasan Politis merupakan bagian yang juga penting dan menjadi dasar pelaksanaan bagi kebijaksanaan yang dibuat khususnya ketata-laksanaan pemerintahan negara. Tujuannya adalah dalam rangka mencapai pembangunan nasional melalui implementasi peraturan perundang-undangan yang disusun sesuai standar dan memiliki manfaat serta arah yang jelas.

Olehnya, Perda sebagai produk hukum ditingkatan bawah (rendah) mestinya dijalankan berdasarkan tuntutan dan keinginan Undang-undang yang lebih di atasnya dalam rangka mencapai kesejahteraan bersama. Selain itu, konsep lain menurut Jazim Hamidi $^{9}$ bahwa Perda sebagai bentuk kewenangan yang diberikan tidak sebatas melihat ketentuan UU yang mengatur Pemerintah Daerah saja, melainkan juga menjadi amanat konstitusi yang dijalankan dengan tidak melanggar ketentuan yang diberikan, antara lain dengan memperhatikan susunan dan tata cara peraturan perundangundangan yang tidak bertentangan dengan kepentingan umum sehingga menuntut pengetahuan yang cukup dari pembuat maupun penyusunnya.

\footnotetext{
9 Jazim Hamidi. (2011). “Legislative Drafting (Seri Naskah Akademik Perda)”. Yogyakarta: Total Media Press. Hal. 5
} 
Rozali Abdullah ${ }^{10}$ berpendapat, bahwa dalam proses pembentukan Perda menyangkut tiga (3) aspek penting, yaitu

1. Aspek Prosedural yakni menyangkut tata cara dan prosedur pembentukan Peraturan Daerah yang secara normatif telah diatur dalam Tata Tertib DPRD masing-masing.

2. Aspek substansial menyangkut isi atau materi pokok yang diatur dalam Peraturan Daerah (latar belakang, tujuan dan objek dibuatnya Peraturan Daerah).

3. Aspek Teknis menyangkut masalah bentuk dan teknis penyusunan Peraturan Daerah (diatur dalam Keputusan Presiden Nomor 44 Tahun 1999 tentang Teknik Penyusunan Peraturan Perundang-undangan dan Bentuk Rancangan Undang-undang, Rancangan Peraturan Pemerintah dan Rancangan Keputusan Presiden).

\section{Asas dalam Peraturan Perundang-undangan}

Hal lain yang patut diperhatikan dalam penerbitan aturan ialah terpenuhinya asas peraturan perundang-undangan yang harus dimiliki agar setiap regulasi yang diterbitkan pejabat berlaku efektif dan tidak bertentangan antara norma yang satu dengan lainnya.

\section{a. Kesesuaian Norma}

Peraturan Daerah seyogianya tidak boleh bertentangan dengan ketentuan di atasnya seperti Undang-undang maupun produk hukum lainnya. Peneliti mengkaji bahwa substansi pengaturan Perda tidak memiliki kesesuaian norma (ada pertentangan norma) yang akan diuraikan melalui table di bawah ini:

\begin{tabular}{|c|c|c|}
\hline No & UU KIP & Perda \\
\hline \multirow[t]{9}{*}{1} & BAB I & BAB I \\
\hline & KETENTUAN UMUM & KETENTUAN UMUM \\
\hline & Pasal 1 & Pasal 1 \\
\hline & (Ayat 12 UU) Pemohon & \\
\hline & $\begin{array}{l}\text { Informasi Publik adalah warga } \\
\text { negara dan/atau badan hukum }\end{array}$ & $\begin{array}{l}\text { Ayat (18) Pemohon adalah setiap warga } \\
\text { negara atau subyek hukum yang cakap }\end{array}$ \\
\hline & Indonesia yang mengajukan & dalam melakukan perbuatan hukum \\
\hline & permintaan informasi publik & yang meminta informasi sebagaimana \\
\hline & sebagaimana diatur dalam & diatur dalam Peraturan Daerah ini. \\
\hline & Undang-Undang ini & \\
\hline
\end{tabular}

\footnotetext{
10 Abdullah, Rozali. (2000). "Produk Hukum Daerah”. Jambi: Pusat Studi dan Hukum Perudang-
} undangan Universitas Jambi. Hal .3 


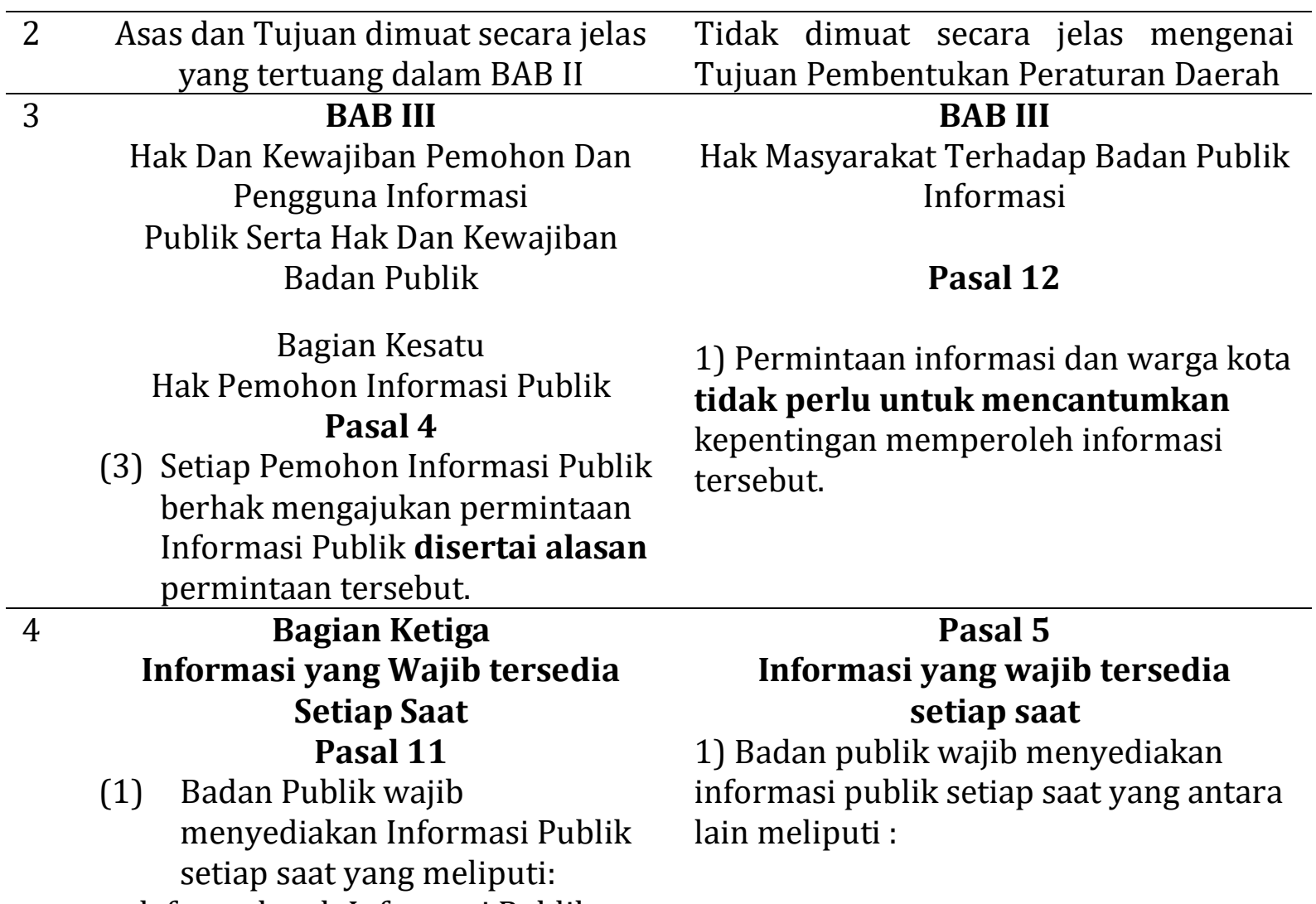

a. daftar seluruh Informasi Publik yang berada di bawah penguasaannya, tidak termasuk informasi yang dikecualikan;
a. daftar dari seluruh informasi publik yang berada dibawah penguasaannya termasuk informasi yang berada dalam kategori pengecualian.

5 Dalam Pasal 14 memuat tentang Informasi Publik yang wajib disediakan oleh Badan Usaha Milik Negara, Badan Usaha Milik Daerah dan/atau badan usaha lainnya yang dimiliki oleh negara dalam UndangUndang

\begin{tabular}{|c|c|c|}
\hline 6 & $\begin{array}{c}\text { BAB VII } \\
\text { KOMISI INFORMASI } \\
\text { Bagian Kedelapan } \\
\text { Pengangkatan dan Pemberhentian } \\
\text { Pasal } \mathbf{3 0} \\
\text { (Point h) pengangkatan anggota } \\
\text { komisi informasi berusia paling } \\
\text { rendah } 35 \text { (tiga puluh lima) } \\
\text { tahun }\end{array}$ & $\begin{array}{l}\text { BAB V } \\
\qquad \begin{array}{l}\text { KOMISI TRANSPARANSI } \\
\text { Pasal } 18\end{array} \\
\text { Pengangkatan dan Pemberhentian } \\
\text { Untuk dapat diangkat sebagai anggota } \\
\text { Komisi Transparansi, seorang calon } \\
\text { harus memenuhi syarat seperti dalam } \\
\text { ayat ( 1) Warga Negara Indonesia } \\
\text { berusia minimal } 27 \text { tahun dan maksimal } \\
60 \text { tahun }\end{array}$ \\
\hline
\end{tabular}


Dari uraian tabel di atas, menunjukkan bahwa ada pertentangan substansi antara aturan yang lebih tinggi dengan Perda Transparansi. Sekilas peneliti juga mengkaji bahwa tujuan atau sasaran yang hendak dicapai Perda jika disandingkan dengan UU ini, maka ada ketidakharmonisan yang mestinya disesuaikan Perda.

Contoh perbedaan (ketidakharmonisan) yakni Pasal 12 Perda dengan_Pasal 4 UU KIP. Permintaan informasi dalam Peraturan Daerah tidak perlu mencantumkan kepentingan memperoleh informasi, sementara UU mengatur hal demikian yang memerintahkan agar permintaan tersebut disertai dengan alasan yang jelas untuk memastikan kepentingan penggunaannya. Melihat persoalan ini, peneliti menyarankan agar perda yang memiliki kekuatan hukum lebih rendah mengikuti UU demi terwujudnya kesesuaian antar keduanya selain juga tidak terjadi pertentangan norma, khususnya jika hal itu bisa berdampak kerugian bagi masyarakat, badan publik dan negara.

Keempat, terdapat pertentangan antara pasal 5 ayat 1 bagian (a) Perda Transparansi dengan Pasal 11 ayat 1 (a) UU KIP, (kolom 4). UU KIP memberikan penekanan bahwa setiap badan publik wajib menyediakan informasi berupa daftar seluruh informasi publik yang ada di bawah penguasaannya dan tidak termasuk informasi yang yang dikecualikan, sementara Perda menegaskan bahwa informasi tersebut termasuk yang berada dalam kategori pengecualian. Bagian ini terdapat suatu pertentangan yang apabila dikaji melalui persoalan hukum, maka Perda jelas menyalahi aturan perudangundangan yang lebih di atasnya termasuk bila dikaji dari sisi ekonomi sosial pernyataan yang ada dalam peraturan daerah bisa berdampak pada kerugian pihakpihak terkait seperti kelompok badan publik yang mengelola masalah keuangan (perbankan), terlebih kerahasiaan kepentingan negara dan masyarakat.

Melihat kenyataan diatas, dapat dinilai tidak adanya persepsi antara perda dengan peraturan di atasnya sehingga disarankan agar peraturan daerah No. 3 Tahun 2002 menyesuaikan perundang-undangan lebih tinggi, dengan tujuan melahirkan kerangka dan konsep hukum menjadi satu kebulatan utuh.

\section{b. Hierarki}

Konsistensi dalam penyusunan peraturan perundang-undangan sangat penting mulai dari perencanaan, perancangan, pembahasan dan perumusan sampai ke tahap 
penetapan agar tidak tumpang tindih. Seperti pembentukan Perda harus memperhatikan kesesuaian antara aturan yang lebih tinggi dengan aturan yang kedudukannya lebih rendah untuk menghindari tidak sinkronnya berbagai produk peraturan.

Jika melihat keberdaan Perda Tranparansi sama persis dengan substansi yang diatur dalam UU Keterbukaan Informasi Publik, dimana kedua aturan tersebut mengatur persoalan serupa, maka berdasarkan hierarki perundang-undangan Perda dapat dibatalkan atau batal demi hukum. Alasannya ialah, secara hierarki Perda merupakan aturan yang lebih rendah dibanding UU. Bunyi asas tingkatan hierarki secara jelas mengatakan bahwa peraturan lebih tinggi kedudukannya memiliki kekuatan hukum yang tinggi pula. Selain itu, asas lain pun menyebut bahwa Undang-undang tidak dapat diganggu gugat, sehingga tak heran jika untuk mencapai keselarasan dan keseimbangan diharapkan produk hukum daerah menyesuaikan dengan hierarki yang ada.

Asas lain menyebutkan pula bahwa Undang-undang yang berlaku belakangan membatalkan undang-undang yang berlaku terdahulu (lex posteriori derogat lex priori), sebagai sarana untuk semaksimal mungkin dapat mencapai kesejahteraan spiritual dan material bagi masyarakat maupun individu, melalui pembaharuan/pelestarian (asas welvaarstaat). Hal ini menjadi patut diperhatikan pemerintah Kota Gorontalo kaitannya dengan kesesuaian perda transparansi terhadap aturan yang lebih tinggi kedudukan dan memuat materi baru yang tidak terdapat dalam perda.

Olehnya, Perda merupakan bagian dari Peraturan Perundang-undangan di tingkat daerah yang langsung bersentuhan dengan kehidupan masyarakat sehingga perlu kesempurnaan dalam penyusunannya baik substansi, prosedur maupun teknik dan materi muatan.

\section{Kesimpulan}

Dari berbagai uraian dan penjelasan sebelumnya, peneliti menyimpulkan bahwa keberadaan Perda Tranparansi belum menggambarkan satu kesatuan sistem hukum 
nasional. Dimana Perda disusun belum sesuai dengan teknik dan landasan pembentukan peraturan perundang-undangan, seperti menyertakan Naskah Akademik yang di dalamnya memuat landasan Filosofis dan Sosiologis. Perda Transparansi juga tidak mencantumkan landasan yuridis (regulasi) yang lebih diatasnya seperti UU Keterbukaan Informasi Publik yang mengatur hal-hal pokok dan serupa, serta tidak mencantumkan materi baru yang dianggap menjadi kebutuhan sebagaimana tertuang dalam UU KIP.

Selain itu, implementasi Perda belum sesuai kaidah yang tertuang dalam UU No. 12 Tahun 2011 dimana perlu memperhatikan dan mengedepankan asas tingkatan (hierarki) agar dalam pelaksanaannya tidak tumpang tindih dengan regulasi yang lebih tinggi.

\section{Saran}

Pemerintah Kota Gorontalo mesti memperbaharui isi (substansi) bahkan mengganti nomenklatur terbaru Perda, dan menyesuaikan dengan teknik penyusunan peraturan perudang-undangan yang baik termasuk menjalankan ketentuan UU No 12 Tahun 2011. Selain itu, meninjau kembali substansi yang bertentangan dengan isi peraturan yang lebih tinggi yakni UU KIP dan menjadikannya sebagai salah satu landasan yuridis Perda demi terpenuhinya asas tingkatan (hierarki) perundang-undangan.

\section{Referensi}

Abdullah, Rozali. (2000). "Produk Hukum Daerah". Jambi: Pusat Studi dan Hukum Perudang-undangan Universitas Jambi

Hamidi, Jazim (ed). (2011). "Legislative Drafting (Seri Naskah Akademik Perda)". Yogyakarta: Penerbit Total Media

Indrati, Maria Farida. (2007). "Ilmu Perundang-undangan(1)”. Yogyakarta: Penerbit Kansius (Cempaka)

Manan, Bagir. (1995). "Sistem dan Tehnik Pembuatan Peraturan Perundang-Undangan Tingkat Daerah". Bandung: Pusat Penerbitan Universitas LPPM- Universitas Islam Bandung

Mertokusumo, Sudikno. (2006). “Penemuan Hukum (Sebuah Pengantar)”. Yogyakarta: Penerbit Liberty

Na'a, Suprin. (2004). "Perda dalam Perspektif Ilmu Perundang-Undangan". Palu: Tadulako University Press 
Purbacaraka, Purnadi (ed). (1993). "Perundang-undangan dan Yurisprudensi". Bandung: Citra Aditya Bakti

Soekanto, Soerjono. (2007). "Pengantar Penelitian Hukum". Jakarta: Penerbit Universitas Indonesia (UI-Press)

Syafrudin, Ateng. (1985). “Pasang Surut Otonomi Daerah”. Bandung: Binacipta 